\title{
Constraints Faced by Farmers in Adoption of Kinnow Growing in Barnala District
}

\author{
Harjot Singh Sohi* and Kamaldeep Singh Matharu \\ Krishi Vigyan Kendra, Handiaya, Barnala (Punjab)-148107, India \\ Guru Angad Dev Veterinary and Animal Sciences University, Ludhiana, Punjab, India \\ *Corresponding author
}

\begin{tabular}{|c|}
\hline Keywords \\
\hline $\begin{array}{l}\text { Weighted Mean Score } \\
\text { (WMS), Constraints, } \\
\text { Cultivation, Fruit, } \\
\text { Kinnow }\end{array}$ \\
\hline Article Info \\
\hline $\begin{array}{l}\text { Accepted: } \\
\text { 06 September } 2018 \\
\text { Available Online: } \\
10 \text { October } 2018\end{array}$ \\
\hline
\end{tabular}

\section{Keywords}

WMS), Constraints,

Kinnow

Accepted:

Available Online:

10 October 2018

\section{A B S T R A C T}

In Punjab, India, Kinnow (Citrus nobilis $\times$ Citrus deliciosa) area and production has increased profusely in arid irrigated and sub-mountainous zones. With all viable environmental conditions present in district Barnala farmers still faced some constraints in Kinnow cultivation. Major constraints in Kinnow plantation: die-back, yield, quality, planting material, technical guidance, socio-cultural, post-harvest management. Present study was conducted with the objective to extent in adoption and perceived constraints in Kinnow cultivation. The constraints as perceived by the respondents were measured by the scores on the basis of magnitude of the problems. While analyzing overall constraints as perceived by farmers the findings revealed that absence of agro processing units WMS (Weighted Mean Score) 2.87, lack of marketing at village level with WMS of 2.84, fruits with prolong juvenile period and higher costs for orchard establishment with WMS of 2.71, continuous adoption of traditional practices for growing fruit WMS of 2.70, lack of involvement of household women in orchards WMS of 2.61, lesser priority is given to orchard plantation than other farm activities WMS of 2.61, lack of knowledge regarding packaging and grading of produce WMS of 2.56, lack of knowledge about recommended fertilizer and manure application WMS of 2.52, lack of knowledge about current advance technologies WMS of 2.47 were major constraints faced by the farmers.

\section{Introduction}

Socio-economic status can be improved through balanced diet, regular source of income. Kinnow belongs to citrus family Rutaceae. It is one of the most famous fruit grown all over the world. In India, citrus occupies $3^{\text {rd }}$ position after Mango and Banana. Citrus plantation is confined within $40^{\circ}$ NorthSouth latitude. The citrus fruits comprising of mandarins (mainly Kinnow), sweet oranges, lime and lemons are of major economic significance in Punjab. It has become exceedingly popular with the growers and consumers in North- India because of its superb fruit quality as compare to other citrus fruits. India is the second largest producer of fruits after China, with a production of 88977 thousand million tonnes of fruits from an area of 7216 thousand hectares (Anonymous, 2017). Today fruits and vegetable farming as a diversified farming is important to generate employment round the year, supplement farm economy and to earn foreign exchange also by 
enhancing the export. As well as fruits play an important role in human nutrition offer diversity indirect, ecological sustainability and fight against hunger. There are many problems associated with adoption of recommended package of practices which may be related to socioeconomic status of farmers and technological awareness which need to be addressed. It is generally stated that the living standard of people can be judged by the production as well as consumption of fruits. These problems reflect the quality of advisory services provided to the farmers. These recommended practices must be followed in totality according to the location specific problems of the area. Imbalanced use of fertilizers, hard pan issues has adversely affected the soil causing decrease in organic carbon, reduction in microbial flora and fauna of soil, increasing alkalinity of soil. The farmers due to negligence tend to apply uneven doses of fertilizer, insecticides etc. Keeping in mind all these perspectives, the study was conducted in the district Barnala, Punjab with following specific objectives includes to study the constraints faced by the farmers and analyze the extent of adoption of mandarin mainly kinnow production practices. Farmer Awerness, training about agronomy practices, irrigation supply, edaptic factors were considered in assessment of production potential and constraint in mango at Bati, Ethiopia by Hussen et al., (2013)

\section{Materials and Methods}

To collect the primary data on prospects of Kinnow cultivation perceived by farmers, the respondents were selected with multistage sampling. Among fruit growing states of India, Punjab was purposively selected being emerging state in Citrus cultivation as well as direct access to the investigators. In Barnala district suitable climate is prevalent for the citrus cultivation. Three blocks viz. MehalKalan, Sehna and Barnala were selected purposively. From these blocks farmers were selected randomly, making a total of 100 respondents. The data were selected with the help of well-structured and pre-tested interview schedule. The schedule consisted major five items like input, technical guidance, socio-culture etc. The responses were obtained on three-point continuum scale in case of prospects (More bright, somewhat bright and not at all bright) and scores were given as 3,2 and 1, respectively. After that frequency was multiplied with the score $(3,2$ or 1) and total weighted score was obtained and total weighted score was divided by total respondents (100) for weighted mean score. In case of mean score which is expressed in percentage, total cumulative frequency was divided by total possible score. The data were analyzed with frequency, weighted frequency, cumulative frequency, weighted mean score, mean score expressed and rank order (Kumar et al., 2016)

\section{Results and Discussion}

\section{Constraints related to inputs}

The results of present study in Table 1 regarding constraints related to input show that 'unavailability of virus free quality seedling' ranked first constraint with weighted mean score (2.46), followed by 'lesser availability of canal water' ranked second major constraint with weighted mean score (2.15), whereas 'high prices of pesticides' were ranked third with weighted mean score (1.83). 'Unavailability of skilled labor' was ranked fourth with weighted mean score (1.48) and 'lesser availability of quality farm yard manure and vermicompost' was ranked fifth with weighted mean score (1.06). The finding of present study concluded that unavailability of virus free quality seedling and lesser availability of canal water was major input related to constraints. Unavailability of recommended seedling at 
desire time might have also contributed towards low production and adoption level of Kinnow cultivation in Barnala District. The study gets support from findings of Biswas and Jamir (2015) who reported that unavailability of quality input material was a serious constraint in kitchen gardening techniques in Mokochung district of Nagaland and Sharma et al., (2011) who highlighted that input constraints were serious constraint in kitchen gardening.

\section{Constraints related to technical guidance}

Data presented of present study in the Table 2 it is clear that among constraints related to technical lack of knowledge about recommended fertilizer and manure application' ranked first constraint with weighted mean score (2.52), followed by 'lack of knowledge about current advance technologies' ranked second with weighted mean score (2.47). 'lack of knowledge regarding major pests and diseases identification' and 'lesser knowledge regarding critical stage of irrigation' were ranked third and fourth with weighted mean score (2.36) and (2.34), respectively. Fifth constraint is management of insect-pest at economic threshold level (ETL) with weighted mean score (2.32) followed by lack of knowledge about soil testing and hard pan issues with weighted mean score (1.96). All these constraints could be minimize by providing training and also by distributing the literature regarding the technical know-how to the farmers as it requires specialized skills in certain operations. The present study revealed that lack of knowledge about recommended fertilizer and manure application and lack of knowledge about current advance technologies were serious constraints. Findings are in agreement with the Samantaray et al., (2009) who reported that lack of advance technologies as major constraint in vegetable production faced by tribal vegetable growers.

\section{Constraints related socio-culture}

Table 3 narrate constraints of present study related to production that 'continuous adoption of traditional practices for growing fruit' ranked first constraint with highest weighted mean score (2.70), followed by 'lack of involvement of household women in fruit plants' ranked second with weighted mean score (2.61). 'Farmers tendency of nonpractice until other farmers in the vicinity opt for orchard plantation' and lack of interest among rural youth and farmers was ranked third and fourth with weighted mean score $(2.45,1.77)$, respectively. The least point is fear of theft of orchard produce with weighted mean score (1.33). The present study also revealed that continuous adoption of traditional practices for growing fruit was major constraint and lack of involvement of household women in fruit plants increased the input cost. These findings are in conformity with study of Sharma et al., (2011) who reported that farmer are growing vegetables by traditional methods and farm women showed less interest in the gardening.

\section{Constraints related to post-harvest}

Findings of the present study (Table 4) revealed that constraints related to technical guidance among which 'absence of agroprocessing units' was considered the most serious constraint by farmers and ranked first with weighted mean score (2.87), followed by 'lack of marketing at village level' ranked second with weighted means score (2.84).

'Lack of knowledge regarding packaging and grading of produce and lack of storage system for surplus produce' was ranked third and fourth with weighted mean score $(2.56,1.46)$ respectively, followed by 'lack of transport facilities and disposal of produce' ranking fifth constraint with weighted mean score (1.15). 
Int.J.Curr.Microbiol.App.Sci (2018) 7(10): 710-719

Table.1 Constraints related to inputs $(n=100)$

\begin{tabular}{|c|c|c|c|c|c|c|c|c|}
\hline $\begin{array}{l}\text { S. } \\
\text { NO }\end{array}$ & Constraints & $\begin{array}{l}\text { Constraints } \\
\text { level }\end{array}$ & Frequency & $\begin{array}{l}\text { Weighted } \\
\text { frequency }\end{array}$ & $\begin{array}{l}\text { Cumulative } \\
\text { frequency }\end{array}$ & $\begin{array}{l}\text { Weighted } \\
\text { mean } \\
\text { score }\end{array}$ & $\begin{array}{l}\text { Mean score } \\
\text { expressed } \\
\text { in } \%\end{array}$ & $\begin{array}{l}\text { Rank } \\
\text { order }\end{array}$ \\
\hline \multirow[t]{3}{*}{1} & \multirow{3}{*}{$\begin{array}{l}\text { Unavailability of virus free } \\
\text { quality seedling }\end{array}$} & High & 67 & 201 & 201 & 2.46 & 82.00 & \multirow[t]{3}{*}{ I } \\
\hline & & Medium & 12 & 24 & 225 & & & \\
\hline & & Low & 21 & 21 & 246 & & & \\
\hline \multirow[t]{3}{*}{2} & \multirow[t]{3}{*}{ Lesser availability of canal water } & High & 31 & 93 & 93 & 2.15 & 71.67 & \multirow[t]{3}{*}{ II } \\
\hline & & Medium & 53 & 106 & 199 & & & \\
\hline & & Low & 16 & 16 & 215 & & & \\
\hline \multirow[t]{3}{*}{3} & \multirow[t]{3}{*}{ Higher prices of pesticides } & High & 32 & 96 & 96 & 1.83 & 61.00 & \multirow[t]{3}{*}{ II } \\
\hline & & Medium & 19 & 38 & 134 & & & \\
\hline & & Low & 49 & 49 & 183 & & & \\
\hline \multirow[t]{3}{*}{4} & \multirow[t]{3}{*}{ Unavailability of Skilled labor } & High & 11 & 33 & 33 & 1.48 & 49.33 & \multirow[t]{3}{*}{ IV } \\
\hline & & Medium & 26 & 52 & 85 & & & \\
\hline & & Low & 63 & 63 & 148 & & & \\
\hline \multirow[t]{3}{*}{5} & \multirow{3}{*}{$\begin{array}{l}\text { Lesser availability of quality } \\
\text { farm yard manure and } \\
\text { vermicompost }\end{array}$} & High & 0 & 0 & 0 & 1.06 & 35.33 & \multirow[t]{3}{*}{ V } \\
\hline & & Medium & 6 & 12 & 12 & & & \\
\hline & & Low & 94 & 94 & 106 & & & \\
\hline
\end{tabular}


Table. 2 Constraints related to technical guidance $(n=100)$

\begin{tabular}{|c|c|c|c|c|c|c|c|c|}
\hline S. NO & Constraints & $\begin{array}{l}\text { Constraints } \\
\text { level }\end{array}$ & Frequency & $\begin{array}{l}\text { Weighted } \\
\text { frequency }\end{array}$ & $\begin{array}{l}\text { Cumulative } \\
\text { frequency }\end{array}$ & $\begin{array}{l}\text { Weighted } \\
\text { mean } \\
\text { score }\end{array}$ & $\begin{array}{l}\text { Mean score } \\
\text { expressed } \\
\text { in } \%\end{array}$ & $\begin{array}{l}\text { Rank } \\
\text { order }\end{array}$ \\
\hline \multirow[t]{3}{*}{1} & \multirow{3}{*}{$\begin{array}{l}\text { Lack of knowledge about } \\
\text { recommended fertilizer and } \\
\text { manure application }\end{array}$} & High & 70 & 210 & 210 & 2.52 & 84.00 & \multirow[t]{3}{*}{ I } \\
\hline & & Medium & 12 & 24 & 234 & & & \\
\hline & & Low & 18 & 18 & 252 & & & \\
\hline \multirow[t]{3}{*}{$\overline{2}$} & \multirow{3}{*}{$\begin{array}{l}\text { Lack of knowledge about } \\
\text { current advance technologies }\end{array}$} & High & 64 & 192 & 192 & 2.47 & 82.33 & \multirow[t]{3}{*}{ II } \\
\hline & & Medium & 19 & 38 & 230 & & & \\
\hline & & Low & 17 & 17 & 247 & & & \\
\hline \multirow[t]{3}{*}{3} & \multirow{3}{*}{$\begin{array}{l}\text { Lack of knowledge regarding } \\
\text { major pests and diseases } \\
\text { identification }\end{array}$} & High & 62 & 186 & 186 & 2.36 & 78.67 & \multirow[t]{3}{*}{ III } \\
\hline & & Medium & 12 & 24 & 210 & & & \\
\hline & & Low & 26 & 26 & 236 & & & \\
\hline \multirow[t]{3}{*}{4} & \multirow{3}{*}{$\begin{array}{l}\text { Lesser knowledge regarding } \\
\text { critical stage of irrigation }\end{array}$} & High & 57 & 171 & 171 & 2.34 & 78.00 & \multirow[t]{3}{*}{ IV } \\
\hline & & Medium & 20 & 40 & 211 & & & \\
\hline & & Low & 23 & 23 & 234 & & & \\
\hline \multirow[t]{3}{*}{5} & \multirow{3}{*}{$\begin{array}{l}\text { Management of insect-pest at } \\
\text { economic threshold level } \\
\text { (ETL) }\end{array}$} & High & 62 & 186 & 186 & 2.32 & 77.33 & \multirow[t]{3}{*}{$\mathrm{V}$} \\
\hline & & Medium & 8 & 16 & 202 & & & \\
\hline & & Low & 30 & 30 & 232 & & & \\
\hline \multirow[t]{3}{*}{6} & \multirow{3}{*}{$\begin{array}{l}\text { Lack of knowledge about hard } \\
\text { pan issues }\end{array}$} & High & 9 & 27 & 27 & 1.96 & 65.33 & \multirow[t]{3}{*}{ VI } \\
\hline & & Medium & 68 & 136 & 163 & & & \\
\hline & & Low & 33 & 33 & 196 & & & \\
\hline
\end{tabular}


Int.J.Curr.Microbiol.App.Sci (2018) 7(10): 710-719

Table.3 Constraints related to socio-culture $(n=100)$

\begin{tabular}{|c|c|c|c|c|c|c|c|c|}
\hline S. NO & Constraints & $\begin{array}{l}\text { Constraints } \\
\text { level }\end{array}$ & Frequency & $\begin{array}{l}\text { Weighted } \\
\text { frequency }\end{array}$ & $\begin{array}{l}\text { Cumulative } \\
\text { frequency }\end{array}$ & $\begin{array}{l}\text { Weighted } \\
\text { mean } \\
\text { score }\end{array}$ & $\begin{array}{l}\text { Mean score } \\
\text { expressed in } \\
\%\end{array}$ & $\begin{array}{l}\text { Rank } \\
\text { order }\end{array}$ \\
\hline \multirow[t]{3}{*}{1} & \multirow{3}{*}{$\begin{array}{l}\text { Continuous adoption of } \\
\text { traditional practices for } \\
\text { growing fruit }\end{array}$} & High & 83 & 249 & 249 & 2.70 & 90.00 & \multirow[t]{3}{*}{ I } \\
\hline & & Medium & 5 & 10 & 259 & & & \\
\hline & & Low & 11 & 11 & 270 & & & \\
\hline \multirow[t]{3}{*}{2} & \multirow{3}{*}{$\begin{array}{l}\text { Lack of involvement of } \\
\text { household women in orchards }\end{array}$} & High & 68 & 204 & 204 & 2.61 & 87.00 & \multirow[t]{3}{*}{ II } \\
\hline & & Medium & 25 & 50 & 254 & & & \\
\hline & & Low & 7 & 7 & 261 & & & \\
\hline \multirow[t]{3}{*}{3} & \multirow{3}{*}{$\begin{array}{l}\text { Farmers' tendency of non- } \\
\text { practice until other farmers in } \\
\text { the vicinity opt for orchard } \\
\text { plantation }\end{array}$} & High & 56 & 168 & 168 & 2.45 & 81.67 & \multirow[t]{3}{*}{ III } \\
\hline & & Medium & 33 & 66 & 234 & & & \\
\hline & & Low & 11 & 11 & 245 & & & \\
\hline \multirow[t]{3}{*}{4} & \multirow{3}{*}{$\begin{array}{l}\text { Lack of interest among rural } \\
\text { youth and farmers }\end{array}$} & High & 25 & 75 & 75 & 1.77 & 59.00 & \multirow[t]{3}{*}{ IV } \\
\hline & & Medium & 27 & 54 & 129 & & & \\
\hline & & Low & 48 & 48 & 177 & & & \\
\hline \multirow[t]{3}{*}{5} & \multirow{3}{*}{$\begin{array}{l}\text { Fear of theft of orchard } \\
\text { produce }\end{array}$} & High & 8 & 24 & 24 & 1.33 & 44.33 & \multirow[t]{3}{*}{ V } \\
\hline & & Medium & 17 & 34 & 58 & & & \\
\hline & & Low & 75 & 75 & 133 & & & \\
\hline
\end{tabular}


Int.J.Curr.Microbiol.App.Sci (2018) 7(10): 710-719

Table.4 Constraints related to post-harvest $(n=100)$

\begin{tabular}{|c|c|c|c|c|c|c|c|c|}
\hline S. NO & Constraints & $\begin{array}{l}\text { Constraints } \\
\text { level }\end{array}$ & Frequency & $\begin{array}{l}\text { Weighted } \\
\text { frequency }\end{array}$ & $\begin{array}{l}\text { Cumulative } \\
\text { frequency }\end{array}$ & $\begin{array}{l}\text { Weighted } \\
\text { mean } \\
\text { score }\end{array}$ & $\begin{array}{l}\text { Mean score } \\
\text { expressed in } \\
\%\end{array}$ & $\begin{array}{l}\text { Rank } \\
\text { order }\end{array}$ \\
\hline \multirow[t]{3}{*}{1} & \multirow{3}{*}{$\begin{array}{l}\text { Absence of agro-processing } \\
\text { units }\end{array}$} & High & 87 & 261 & 261 & 2.87 & 95.67 & \multirow[t]{3}{*}{ I } \\
\hline & & Medium & 13 & 26 & 287 & & & \\
\hline & & Low & 0 & 0 & 287 & & & \\
\hline \multirow[t]{3}{*}{2} & \multirow{3}{*}{$\begin{array}{l}\text { Lack of marketing at village } \\
\text { level }\end{array}$} & High & 86 & 258 & 258 & 2.84 & 94.67 & \multirow[t]{3}{*}{ II } \\
\hline & & Medium & 12 & 24 & 282 & & & \\
\hline & & Low & 2 & 2 & 284 & & & \\
\hline \multirow[t]{3}{*}{3} & \multirow{3}{*}{$\begin{array}{l}\text { Lack of knowledge } \\
\text { regarding packaging and } \\
\text { grading of produce }\end{array}$} & High & 52 & 156 & 156 & 2.56 & 85.33 & \multirow[t]{3}{*}{ III } \\
\hline & & Medium & 42 & 84 & 240 & & & \\
\hline & & Low & 16 & 16 & 256 & & & \\
\hline \multirow[t]{3}{*}{4} & \multirow{3}{*}{$\begin{array}{l}\text { lack of storage system for } \\
\text { surplus produce }\end{array}$} & High & 4 & 12 & 12 & 1.46 & 48.67 & \multirow[t]{3}{*}{ IV } \\
\hline & & Medium & 38 & 76 & 88 & & & \\
\hline & & Low & 58 & 58 & 146 & & & \\
\hline \multirow[t]{3}{*}{5} & \multirow{3}{*}{$\begin{array}{l}\text { Lack of transport facilities } \\
\text { and disposal of produce }\end{array}$} & High & 0 & 0 & 0 & 1.15 & 38.33 & \multirow[t]{3}{*}{ V } \\
\hline & & Medium & 15 & 30 & 30 & & & \\
\hline & & Low & 85 & 85 & 115 & & & \\
\hline
\end{tabular}


Table.5 Constraints related to general problems $(n=100)$

\begin{tabular}{|c|c|c|c|c|c|c|c|c|}
\hline S. NO & Constraints & $\begin{array}{l}\text { Constraints } \\
\text { level }\end{array}$ & Frequency & $\begin{array}{l}\text { Weighted } \\
\text { frequency }\end{array}$ & $\begin{array}{l}\text { Cumulative } \\
\text { frequency }\end{array}$ & $\begin{array}{l}\text { Weighted } \\
\text { mean } \\
\text { score }\end{array}$ & $\begin{array}{l}\text { Mean score } \\
\text { expressed } \\
\text { in } \%\end{array}$ & $\begin{array}{l}\text { Rank } \\
\text { order }\end{array}$ \\
\hline \multirow[t]{3}{*}{1} & \multirow{3}{*}{$\begin{array}{l}\text { Prolong juvenile period and } \\
\text { higher costs for orchard } \\
\text { establishment }\end{array}$} & High & 78 & 234 & 234 & 2.71 & 90.33 & \multirow[t]{3}{*}{$\mathrm{I}$} \\
\hline & & Medium & 15 & 30 & 264 & & & \\
\hline & & Low & 7 & 7 & 271 & & & \\
\hline \multirow[t]{3}{*}{2} & \multirow{3}{*}{$\begin{array}{l}\text { Lesser priority is given to } \\
\text { orchard plantation than other } \\
\text { farm activities }\end{array}$} & High & 74 & 222 & 222 & 2.61 & 87.00 & \multirow[t]{3}{*}{ II } \\
\hline & & Medium & 13 & 26 & 248 & & & \\
\hline & & Low & 13 & 13 & 261 & & & \\
\hline \multirow[t]{3}{*}{3} & \multirow[t]{3}{*}{ No support price } & High & 63 & 189 & 189 & 2.44 & 81.33 & \multirow[t]{3}{*}{ III } \\
\hline & & Medium & 18 & 36 & 225 & & & \\
\hline & & Low & 19 & 19 & 244 & & & \\
\hline \multirow[t]{3}{*}{4} & \multirow{3}{*}{$\begin{array}{l}\text { Soil testing upto } 200 \mathrm{~cm} \text { for } \\
\mathrm{pH} \text { and } \mathrm{EC}\end{array}$} & High & 35 & 105 & 105 & 1.94 & 64.67 & \multirow[t]{3}{*}{ IV } \\
\hline & & Medium & 24 & 48 & 153 & & & \\
\hline & & Low & 41 & 41 & 194 & & & \\
\hline \multirow[t]{3}{*}{5} & \multirow{3}{*}{$\begin{array}{l}\text { Problem of proper protection } \\
\text { of local cattle grazing }\end{array}$} & High & 24 & 72 & 72 & 1.89 & 63.00 & \multirow[t]{3}{*}{ V } \\
\hline & & Medium & 31 & 62 & 134 & & & \\
\hline & & Low & 55 & 55 & 189 & & & \\
\hline
\end{tabular}


Information communication technologies (ICT) facilities can also play great role in mitigating these constraints. The present studies are agreement the findings of Kumar et al., (2016) who also reported that absence of agro-processing units are the major concerns.

\section{General constraints as perceived by respondents}

An examination of results of present study in Table 5 indicate that among general constraints 'prolong juvenile period and higher costs for orchard establishment' was a major problem with weighted mean score (2.71), followed by 'lesser priority is given to orchard plantation than other farm activities' as second important constraint with weighted mean score (2.61). 'No support price' and 'soil testing for orchard' were ranked third and fourth with weighted mean scores (2.44) and (1.94), respectively. The last problem of proper protection from local grazing animals with weighted mean score (1.89).Present study also revealed that longer time taken in fruit bearing and lesser priority given to fruit plant were major general constraints faced by the respondents.

Findings are in agreement with the study of Singh et al., (2010) who found that weak extension activities at village level were the major constraint in rice production technology. These findings are in line with the findings of Choudhary and Bangarwa (2013) who concluded that the constraints most perceived by the farmers in adoption were high initial cost in establishing of orchard, irregular water supply from canal, lack of proper market and lack of need based training in Kinnow production by the farmers of Sri-Ganganagar district of Rajasthan and Singh (2004) reported that inadequate training for technical skills was major constraint in mango fruit production.
The present study concluded that unavailability of virus free quality planting seedling was major constraints related to inputs while lack of knowledge about recommended fertilizer and manure application and lack of knowledge about current advance technologies were serious constraints pertaining technical. Hard pan in some areas of district barnala caused die-back of aged Kinnow crop leads to uprooting of orchards is a major constraint in relation to socio-culture, continuous adoption of traditional practices for growing fruit and lack of involvement of household women in fruit plants were important constraints. Absence of agro-processing units and lack of marketing at village level were major post-harvest constraints. Prolong juvenile period and higher costs for orchard establishment and lesser priority is given to orchard plantation than other farm activities etc. were major general constraints perceived by farmers. So, the government should address the problem of better technical support and credit facilities for wider adoption of this fruit crop.

\section{References}

Anonymous. 2017. National Horticulture Database 2016- 17, National Horticulture Board, Ministry of Agriculture, Govt. of India, Gurgaon.

Biswas, P.K., Jamir, S. 2015. "Constraints faced by farmers an adoption of kitchen gardening techniques in Mokochung district of Nagaland". International Journal of Farm Sciences. 5(3): 207211.

Choudhary, H.D., Bangarwa, G.S. 2013. "Knowledge and constraints in recommended kinnow production technology among the kinnow growers". International Journal of Agricultural Sciences. 9(2): 472-275.

Hussen, S., Yimer, Z. 2013. "Assessement of production potential and constraints of 
mango at Bhati, Oromiya Zone, Ethiopia". International Journal of Science: Basic and Applied Research. 11(1): 1-9.

Parashar, M.P. 2009. "Post-Harvest Profile of Mandarin", Govt. of India Ministry of Agriculture (Department of Agriculture \& Cooperation) Directorate of Marketing \& Inspection Branch Head office Nagpur.

Samantaray, S.K., Prusty, S., Raj, R.K. 2009. "Con-straints in vegetable production experiences of tribal vegetable growers". Indian Research Journal of Exten-sion Education. 9(3): 32-34.

Sharma, A., Singh, B. K., Anand, N. 2016. "Fruit Processing Industry in India: A Short Review" book: Cold Chain
Logistics in Horticulture \& Agriculture, Edition: first, Publisher: Winsar Publishing Company, pp: 1-17.

Sharma, K., Singh, G., Dhaliwal, N.S., Yadav, Y.P.S. 2011. "Constraints in adoption of recommended kitchen gardening techniques". Journal of Community Mobilization and Sustainable Development. 6(1): 96-99.

Singh, M. 2004. "Adoption and constraints in mango cultivation". M.Sc. Thesis (unpublished) Department of Ext. Edu., CCSHAU, Hisar.

Singh, P.K., Varshney and Jay, G. 2010. "Adoption level and constraints in rice production technology". Indian Research Journal of Extension Education. 10(1): 91-94.

\section{How to cite this article:}

Harjot Singh Sohi and Kamaldeep Singh Matharu. 2018. Constraints Faced by Farmers in Adoption of Kinnow Growing in Barnala District. Int.J.Curr.Microbiol.App.Sci. 7(10): 710719. doi: https://doi.org/10.20546/ijcmas.2018.710.078 